\title{
Expression of IAP family proteins and its clinical importance in breast cancer patients
}

\author{
P. PLUTA ${ }^{1}$, A. JEZIORSKI ${ }^{1}$, A. PLUTA ${ }^{2, *}$, B. CEBULA-OBRZUT ${ }^{3}$, A. WIERZBOWSKA ${ }^{2}$, J. PIEKARSKI ${ }^{1}$, P. SMOLEWSKI $^{3}$
}

${ }^{1}$ Department of Surgical Oncology, Medical University of Lodz, Copernicus Memorial Hospital, Lodz, Poland; ${ }^{2}$ Department of Hematology, Medical University of Lodz, Copernicus Memorial Hospital, Lodz, Poland; ${ }^{3}$ Department of Experimental Hematology, Medical University of Lodz, Copernicus Memorial Hospital, Lodz, Poland

*Correspondence: piotr.pluta@umed.lodz.pl

Received February 5, 2014 / Accepted March 12, 2015

\begin{abstract}
Inhibitor of apoptosis (IAP) family proteins is involved in mechanisms of resistance to apoptosis in various cancer cells. The aim of this study was to assess the expression of selected IAP proteins such as XIAP, cIAP-1, cIAP-2 and survivin in breast cancer patients and evaluates their relationship with the prognostic and predictive factors and their impact to overall survival (OS) and progression free survival (PFS). The study was conducted with the use of tissue samples prospectively collected from 92 previously untreated female breast cancer patients. The control encompassed 10 fibroadenoma patients. The expression of XIAP, cIAP-1, cIAP-2 and survivin was assessed using flow multicolor cytometry. XIAP expression was present in $99 \%$ of the breast cancer patients (91/92) with the median expression 13.65\% (range 1-66.8\%). Expression of XIAP in breast cancer was significantly higher compared to the control group ( $\mathrm{p}=0.006)$. Median expression of cIAP-1, cIAP-2 and survivin in the study group was $25.95 \%$ (range $0.8-83.7 \%$ ), $16.7 \%$ (range $1-53.2 \%$ ) and $4.6 \%$ (range $0-43 \%$ ) respectively. In the rank Spearman test, strong correlations $(\mathrm{p}<0.001)$ were seen among the expressions of XIAP, cIAP- 2 and survivin, in all combination. Additionally, week correlation between XIAP and cIAP-1 was observed $(\mathrm{p}=0.02)$. The median expression of XIAP and survivin was significantly higher in more advanced tumors (stages pT2/pT3 vs. pT1). The median PFS and OS in breast cancer group were 46.15 and 47.1 months respectively. No significant correlations were observed among expressions of IAP family proteins and survival. However, low expression of XIAP in breast cancer showed trend to longer PFS ( $\mathrm{p}=0.08$ ). XIAP, cIAP-1 cIAP-2 and survivin participate in antiapoptotic mechanisms in breast cancer and XIAP and survivin seem to have the most significant prognostic importance. Further studies are needed to establish more complete prognostic and predictive values of IAP family proteins in breast cancer patients.
\end{abstract}

Key words: IAP family proteins - apoptosis - breast cancer - prognosis

Breast cancer is the most common malignancy seen in female patients worldwide [1]. During last decades major advances have been made in screening for risk factors associated with breast cancer in high-prevalence areas [2]. Knowledge regarding clinical symptoms of breast cancer and the possibilities of screening tests among healthy population is higher comparing to the other malignancies and wide acceptance among women for breast cancer screening results in increased detection rate of early breast cancer [3]. Additionally to improve long term outcome multidisciplinary approach including surgery, chemotherapy and radiotherapy is proposed to most breast cancer patients. Despite this facts, almost $80 \%$ of operable, node positive breast cancer patients after adjuvant treatment die from progression of the disease within 30 years of diagnosis [4]. An understanding of the molecular pathways of breast cancer development may contribute toward an improvement of the outcome of treatment by introducing new, more effective therapies.

Apoptosis is the process by which damaged cells, including cancer cells, are eliminated, and aberrant suppression of apoptosis is one of the mechanisms responsible for cancer development $[5,6]$. Besides the $\mathrm{Bcl}-2$ family proteins, the most potent antiapoptotic factors are the inhibitors of apoptosis (IAP) family proteins that bear structural similarity to baculoviral IAP repeat (BIR) domains at the N-terminus [7, 8, 9]. These domains are responsible for inhibition of apoptosis by binding the active sites of caspases, which are the crucial proteases in apoptotic pathways. The second well-described 
domain present in some IAP members is a particularly interesting new gene (RING) domain at the C-terminus. This domain behaves as ubiqiutin protein ligase (E3), which is the final labeling enzyme targeting the proteins for degradation [10]. Eight IAP proteins have been found in humans, including cellular IAP-1 (cIAP-1), cellular IAP-2 (cIAP-2), $\mathrm{X}$ chromosome-linked IAP (XIAP), survivin, BIR repeatcontaining ubiquitin conjugating enzymesystem (BRUCE), neuronal apoptosis inhibitory protein (NAIP), melanoma IAP (MLIAP) and IAP-like protein 2 (ILP2) [11].

IAP family proteins are present in most normal tissues and play an important role as inhibitors of apoptosis $[5,6]$. However, these proteins seem to be responsible for resistance to apoptosis in cancer cells. The association between upregulation of IAP family proteins, such as XIAP, cIAP-1, cIAP-2 and survivin, and an unfavorable course of disease has been confirmed in chronic lymphocytic leukemia [12]. Also, pathological overexpression of IAP family members has been observed in various solid tumors including prostate cancer, breast cancer, pancreatic cancer, gastric cancer and melanoma [13-18].

In breast cancer, the overexpression of XIAP and survivin have been found to be overexpressed in both breast cancer cell lines and in tumor tissues [14,19]. Although overexpression of survivin is associated with poor prognosis in most human cancers, the prognostic role of this protein is ambiguous in breast cancer patients $[14,20,21]$. Knowledge regarding the expression of the other IAP family members is limited, especially concerning the clinicopathological data of breast cancer.

In this paper we describe the expression of 4 most potent IAP family members including XIAP, cIAP-1, cIAP-2 and survivin in breast cancer patients. To our knowledge, this is the first study, where the expression of IAP's family panel was assessed in breast cancer patients using flow multicolor cytometry, with the aim of evaluating their relationship with the prognostic and predictive factors of breast cancer. The impact of the expression of XIAP, cIAP-1, cIAP-2 and survivin proteins to the overall survival (OS) and disease free survival (PFS) was also evaluated.

\section{Patients and methods}

Patients and specimens. The study was conducted with the use of tissue samples prospectively collected from 92 previously untreated female breast cancer patients operated on at the Department of Surgical Oncology, Medical University of Lodz, between January 2008 and December 2010. The median age of patients was 59 years (range 38-89) (Table 1). The control encompassed 10 fibroadenoma patients (median age 30 years; range 24-53). The staging was assessed according to the 2010 pTNM AJCC/UICC classification. Tumor specimens were obtained during surgery and stored at $-80^{\circ} \mathrm{C}$ until needed. Approval for the study was obtained from the Ethics Committee of the Medical University of Lodz.
Specimens processing and flow-cytometry assessment. Methods of sample collecting and flow cytometry processing are described in detail elsewhere [22]. Briefly, about 0.5 to $1 \mathrm{~cm}^{3}$ fresh tissues were collected immediately from the resected tumors and stored frozen in $-80^{\circ} \mathrm{C}$. Preparing to the cytometry assessment, defrosted tissues were suspended in $2.1 \%$ citric acid $/ 0.5 \%$ Tween 20 . Cell suspensions were fixed in $70 \%$ ethanol and phosphate buffered saline (PBS; Sigma Aldrich Chemie Gmbh, Steinheim, Germany). Then they were incubated in $0.01 \%$ saponin (Sigma Aldrich Chemie Gmbh, Steinheim, Germany) for 1 min. afterwards, the cells were incubated with primary antibodies at a dilution of 1:100 (anti-XIAP, anti-cIAP-1, anti-cIAP-2, anti-survivin; all polyclonal goat Ab, R\&D System, Minneapolis, MN, USA) at $4^{\circ} \mathrm{C}$, overnight. On the following day, the samples were incubated with secondary FITC-conjugated Abs at dilution 1:20 for $120 \mathrm{~min}$. The samples were then resuspended in 400ul PBS and subjected to flow cytometry analysis. Simultaneously, samples with isotype controls were prepared (Normal Goat IgG control, 1:100 dilutions, R\&D System, Minneapolis, MN, USA).

Flow cytometry analysis. All measurements were performed using flow cytometry (FACScan; Becton-Dickinson, San Jose, CA, USA). An acquisition gate was established based on FSC (forward scatter) versus SSC (side scatter) distribution, which included cells according to previous immunophenotype (cytokeratine 19). Cell fluorescence was measured using standard emission filters: FL1 (green, 515-545nm). For each analysis 10,000 events were acquired and analyzed using CellQuestPro software (Becton Dickinson, San Jose, CA, USA).

The IAP-s-positive cells were identified after gating based on appropriate isotype controls. Expression of XIAP, cIAP-1, cIAP-2, survivin was presented as a percentage of positive cells

Table 1. Clinical and pathological characteristic of study group ( $n=92)$.

\begin{tabular}{lcc}
\hline Variables & Number & $\%$ \\
\hline Age & 12 & 13 \\
$<50 \mathrm{yr}$ & 80 & 87 \\
$\geq 50 \mathrm{yr}$ & & \\
\hline Tumor stage (pT) & 34 & 37 \\
T1 & 58 & 63 \\
T2, T3 & & \\
\hline Lymph node status (pN) & 35 & 38 \\
N0 & 57 & 62 \\
N1, N2, N3 & & \\
Histological type of cancer & & 15 \\
Histological grade & 14 & 85 \\
G1 & 78 & 77 \\
G2 and G3 & & 23 \\
\hline Receptor status & 71 & 67 \\
ER positive & 21 & 33 \\
ER negative & 62 & 23 \\
PR positive & 30 & 77 \\
PR negative & 21 & \\
Her-2 positive & 71 & \\
Her-2 negative & &
\end{tabular}


in the whole population of tumor cells. All flow cytometry measurements were performed on 10,000 cells per sample. "High" and "low" expression levels were established based on the median of XIAP, cIAP-1, cIAP-2, survivin -positive cells estimated in the whole group of patients (Figure 1).

Statistical analysis. Statistical analysis was performed with the use of Statistica 7.0 (Tulusa, OK, USA) software. The expression of the evaluated proteins in the study group and control was compared with the Mann-Whitney $U$ test. Correlations between variables were assessed by the Spearman rank correlation coefficient (R). PFS and OS were assessed using Kaplan-Meier method. The log-rank test was used for comparison of OS and PFS in subsequent subgroups. P values $\mathrm{p}<0.05$ were considered statistically significant.

The overall survival (OS) is defined as the time from the start of treatment to death from any cause. The progression free survival (PFS) is defined as the time from the start of treatment until objective tumor progression or death.

\section{Results}

Expression of XIAP, cIAP-1, cIAP-2 and survivin in breast cancer group and control. XIAP expression was present in $99 \%$ of the breast cancer patients (91/92). The median expression of XIAP in this group was 13.65\% (range 0.1-66.8\%). In the control, XIAP was found to be expressed in $80 \%$ of the patients. Median expression of XIAP in the control was $3.35 \%$ and ranged from 0.1 to $39 \%$. Expression of XIAP in breast cancer was significantly higher compared to the control group ( $\mathrm{p}=0.006)$.

Median expression of cIAP-1, cIAP-2 and survivin in the study group was $25.95 \%$ (range $0.2-79.1 \%$ ), $16.7 \%$ (range 0.3 $62.2 \%$ ) and $4.6 \%$ (range $0-12.3 \%$ ) respectively. These results were not significantly different compared to the control. The expression of evaluated proteins is summarized in Table 2.

In the rank Spearman test, strong correlations $(\mathrm{p}<0.001)$ were seen among the expressions of XIAP, cIAP- 2 and survivin, in all combination. Additionally, week correlation between XIAP and cIAP- 1 was observed ( $\mathrm{p}=0.02$ ) (Table 3 ).

Correlation of XIAP, cIAP-1, cIAP-2 and survivin expression with clinico-pathological characteristics. In the study group, the median expression of XIAP and survivin was significant higher in more advanced tumors (stages pT2/ pT3 vs. pT1). Additionally, XIAP expression was associated with the presence of estrogen receptor in tumors. The median expression of cIAP-2 was higher in node positive breast cancer (pN1-N3). Relations among proteins expression and clinicopathological characteristic of study group were summarized in Table 4.

Influence of XIAP, cIAP-1, cIAP-2 and survivin expression on progression free survival (PFS) and overall survival (OS). The median PFS for the study group was 46.15 months (range 8.1-71.3). Better PFS was influenced by node negative and ER positive breast cancer ( $\mathrm{p}=0.006$ and $\mathrm{p}=0.048$ respectively; Table 4). Trend to longer PFS was observed in patients
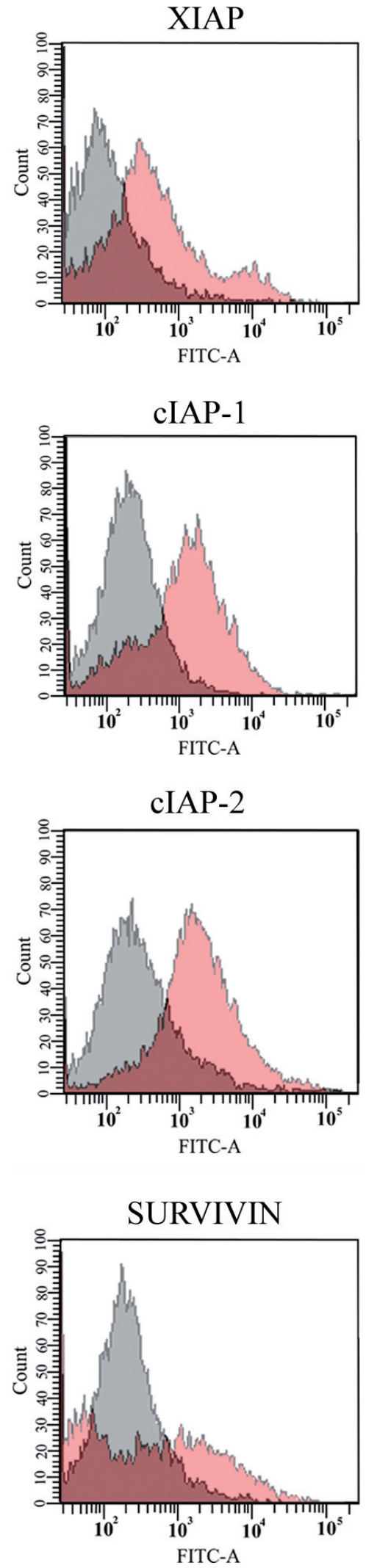

Figure 1. Ecxpression of XIAP, cIAP-1, cIAP-2, survivin with isotyte controls in flow cytometry, 
Table 2. Expression of XIAP, cIAP-1, cIAP-2 and survivin in breast cancer group and control

\begin{tabular}{|c|c|c|c|c|c|c|c|}
\hline & $\begin{array}{c}\text { Number of } \\
\text { positive samples } \\
\text { in study group }\end{array}$ & $\begin{array}{c}\text { Median } \\
\text { expression in } \\
\text { study group (\%) }\end{array}$ & $\begin{array}{c}\text { Range of } \\
\text { expression in } \\
\text { study group (\%) }\end{array}$ & $\begin{array}{c}\text { Number of } \\
\text { positive samples } \\
\text { in control }\end{array}$ & $\begin{array}{c}\text { Median } \\
\text { expression in } \\
\text { control }(\%)\end{array}$ & $\begin{array}{c}\text { Range of } \\
\text { expression in } \\
\text { control group (\%) }\end{array}$ & $\begin{array}{c}\mathrm{p} \text { value for median } \\
\text { expression } \\
\text { comparison }\end{array}$ \\
\hline XIAP & $91 / 92(99 \%)$ & 13.65 & $0.1-66.8$ & $8 / 10(80 \%)$ & 3.35 & $0.1-39$ & 0.006 \\
\hline cIAP-1 & $92 / 92(99 \%)$ & 25.95 & $0.2-79.1$ & $10 / 10(100 \%)$ & 17.6 & $0.2-79.1$ & ns \\
\hline CIAP-2 & $92 / 92(100 \%)$ & 16.7 & $0.3-62.2$ & $10 / 10(100 \%)$ & 8.9 & $0.3-65.8$ & ns \\
\hline survivin & $90 / 92(98 \%)$ & 4.6 & $0-12.3$ & $9 / 10(90 \%)$ & 4.0 & $0-38.9$ & ns \\
\hline
\end{tabular}

$\mathrm{ns}=$ not significant

Table 3. Relationships among XIAP, cIAP-1, cIAP-2 and survivin expression in rank-Spearman test.

\begin{tabular}{|c|c|c|c|c|}
\hline & XIAP & cIAP-1 & cIAP-2 & Survivin \\
\hline \multirow[t]{2}{*}{ XIAP } & $\mathrm{x}$ & $\mathrm{P}=0.02$ & $\mathrm{p}<0.001$ & $\mathrm{p}<0.001$ \\
\hline & & $\mathrm{R}=0.16$ & $\mathrm{R}=0.40$ & $\mathrm{R}=0.40$ \\
\hline \multirow[t]{2}{*}{ cIAP-1 } & $\mathrm{p}=0.02$ & $\mathrm{x}$ & $\mathrm{p}<0.001$ & $\mathrm{p}<0.001$ \\
\hline & $\mathrm{R}=0.16$ & & $\mathrm{R}=0.58$ & $\mathrm{R}=0.69$ \\
\hline \multirow[t]{2}{*}{ cIAP-2 } & $\mathrm{p}<0.001$ & $\mathrm{p}<0.001$ & $\mathrm{x}$ & $\mathrm{p}<0.001$ \\
\hline & $\mathrm{R}=0.40$ & $\mathrm{R}=0.58$ & & $\mathrm{R}=0.50$ \\
\hline \multirow[t]{2}{*}{ survivin } & $\mathrm{p}<0.001$ & $\mathrm{p}<0.001$ & $\mathrm{p}<0.001$ & $\mathrm{X}$ \\
\hline & $\mathrm{R}=0.40$ & $\mathrm{R}=0.69$ & $\mathrm{R}=0.50$ & \\
\hline
\end{tabular}

Table 4. Clinico-pathological features of breast cancer patients $(n=92)$ and expression of IAP proteins.

\begin{tabular}{|c|c|c|c|c|}
\hline Characteristic & $\begin{array}{l}\text { XIAP median (range) } \\
\text { expression }\end{array}$ & $\begin{array}{l}\text { cIAP-1 median (range) } \\
\text { expression }\end{array}$ & $\begin{array}{l}\text { cIAP-2 median (range) } \\
\text { expression }\end{array}$ & $\begin{array}{l}\text { Survivin median (range) } \\
\text { expression }\end{array}$ \\
\hline \multicolumn{5}{|l|}{ Age } \\
\hline$<50$ years & $4.3(0.6-66.0)$ & $18.5(0.2-52.0)$ & $10.1(1.6-53.2)$ & $2.1(0-8.2)$ \\
\hline$\geq 50$ years & $3.4(0.1-27.6)$ & $18.9(0.5-79.1)$ & $9.5(0.3-62.2)$ & $1.4(0-12.3)$ \\
\hline$p$-value & 0.96 & 0.35 & 0.76 & 0.66 \\
\hline \multicolumn{5}{|l|}{ Tumor stage } \\
\hline pT1 & $1.9(0.1-19.8)$ & $14.9(0.2-69.3)$ & $7.4(0.3-62.2)$ & $1.15(0-12.3)$ \\
\hline pT2/pT3 & $6.6(0.1-33.4)$ & $21(0.5-79.1)$ & $10.3(1.7-60.5)$ & $1.7(0-9.6)$ \\
\hline p-value & 0.02 & 0.36 & 0.07 & 0.18 \\
\hline \multicolumn{5}{|l|}{ Node stage } \\
\hline pNo & $2.9(0.1-19.8)$ & $15.3(0.6-56.2)$ & $6.8(0.3-37.8)$ & $1.2(0.1-8.6)$ \\
\hline $\mathrm{pN} 1 / \mathrm{pN} 2 / \mathrm{pN} 3$ & $5.3(0.1-33.4)$ & $19.7(0.2-79.1)$ & $12.5(1.7-62.2)$ & $1.7(0-12.3)$ \\
\hline p-value & 0.26 & 0.47 & 0.02 & 0.47 \\
\hline \multicolumn{5}{|l|}{ Tumor grade } \\
\hline G1 & $2.6(0.1-27.6)$ & $17.6(0.2-79.1)$ & $8.0(0.3-42.3)$ & $1.6(0-9.6)$ \\
\hline $\mathrm{G} 2 / \mathrm{G} 3$ & $2.6(0.9-16.6)$ & $48.1(6.6-57.3)$ & $8.6(7.2-25.0)$ & $1.2(0.6-2.2)$ \\
\hline $\mathrm{p}$-value & 0.98 & 0.19 & 0,58 & 0.84 \\
\hline \multicolumn{5}{|l|}{ ER status } \\
\hline positive & $5.9(0.1-33.4)$ & $15.6(0.4-79.1)$ & $9.3(0.6-42.3)$ & $1.7(0.1-9.6)$ \\
\hline negative & $2.2(0.1-13.9)$ & $21.0(0.2-69.3)$ & $6.4(0.3-27.3)$ & $0.8(0-9.1)$ \\
\hline p-value & 0.03 & 0.5 & 0.85 & 0.11 \\
\hline \multicolumn{5}{|l|}{ PR status } \\
\hline positive & $3.2(0.4-33.4)$ & $19.2(0.4-79.1)$ & $9.7(0.6-42.3)$ & $1.7(0.1-9.6)$ \\
\hline negative & $2.8(0.1-13.9)$ & $15.3(0.2-69.3)$ & $5.1(0.3-37.8)$ & $0.8(0-9.1)$ \\
\hline $\mathrm{p}$-value & 0.12 & 0.38 & 0.07 & 0.27 \\
\hline \multicolumn{5}{|l|}{ Her-2 status } \\
\hline Positive & $4.1(0.6-14.7)$ & $19.4(0.4-46.8)$ & $7.9(1.3-36.4)$ & $0.8(0.1-4.7)$ \\
\hline negative & $3.0(0.1-33.4)$ & $14.2(0.2-79.1)$ & $10.7(0.3-42.3)$ & $1.2(0-9.6)$ \\
\hline $\mathrm{p}$-value & 0.52 & 0.77 & 0.32 & 0.1 \\
\hline \multicolumn{5}{|c|}{$\begin{array}{l}\text { Triple negative (ER -, } \\
\text { PR-, Her-2 -) }\end{array}$} \\
\hline Yes & $3.6(0.1-33.4)$ & $19.4(0.4-79.1)$ & $8.6(0.6-42.3)$ & $1.6(0.1-9.6)$ \\
\hline No & $2.2(0.1-9.1)$ & $5.0(0.2-69.3)$ & $4.6(0.7-27.3)$ & $0.8(0-9.1)$ \\
\hline $\mathrm{p}$-value & 0.26 & 0.74 & 0.80 & 0.99 \\
\hline
\end{tabular}


with low expression of XIAP compared to "high expressors" ( $\mathrm{p}=0.08$, Table 4). CIAP-1, cIAP-2 and survivin did not influence PFS (Table 5).

The median OS for evaluable breast cancer patients was 47.1 , ranged from 13.8 to 71.3 months. Better OS was observed in node negative breast cancer patients (Table 6). Expression of XIAP, cIAP-1, cIAP-2 and survivin in study group did not impact OS.

\section{Discussion}

In this study we have observed expression of XIAP, cIAP-1, cIAP-2 and survivin in samples taken from both breast cancer and fiboradenoma, the latter constituting the control, which may indicate that the development of these two types of breast

Table 5. Factors associated with probability of PFS (univariate analysis - log-rank test)

\begin{tabular}{|c|c|c|c|}
\hline Factor & $\mathrm{n}$ & $\begin{array}{c}\text { PFS at } \\
36 \text { months } \\
(\%)\end{array}$ & $\mathrm{p}$ \\
\hline Age & & & 0.75 \\
\hline$<50 \mathrm{yr}$ & 12 & 83 & \\
\hline$\geq 50 \mathrm{yr}$ & 80 & 87 & \\
\hline Grade & & & 0.30 \\
\hline G1 & 14 & 100 & \\
\hline G2 and G3 & 78 & 83 & \\
\hline Tumor & & & 0.01 \\
\hline $\mathrm{T} 1$ & 34 & 100 & \\
\hline $\mathrm{T} 2, \mathrm{~T} 3$ & 58 & 77 & \\
\hline Node & & & 0.006 \\
\hline No & 35 & 100 & \\
\hline $\mathrm{N} 1, \mathrm{~N} 2, \mathrm{~N} 3$ & 57 & 77 & \\
\hline ER & & & 0.048 \\
\hline Positive & 71 & 92 & \\
\hline Negative & 21 & 73 & \\
\hline PR & & & 0.4 \\
\hline Positive & 62 & 90 & \\
\hline Negative & 30 & 83 & \\
\hline HER-2 & & & 0.34 \\
\hline Positive & 21 & 86 & \\
\hline Negative & 71 & 90 & \\
\hline \multicolumn{4}{|c|}{ Triple negative (ER -, PR-, Her-2 -) } \\
\hline Yes & 13 & 86 & 0.32 \\
\hline No & 79 & 100 & \\
\hline XIAP & & & 0.08 \\
\hline$\leq \mathrm{Me}$ & 46 & 100 & \\
\hline$>\mathrm{Me}$ & 46 & 76 & \\
\hline cIAP-1 & & & 0.62 \\
\hline$\leq$ Median & 46 & 88 & \\
\hline$>$ Median & 46 & 81 & \\
\hline cIAP-2 & & & 0.57 \\
\hline$\leq$ Median & 46 & 90 & \\
\hline$>$ Median & 46 & 81 & \\
\hline Survivin & & & 0.85 \\
\hline$\leq$ Median & 46 & 84 & \\
\hline$>$ Median & 46 & 84 & \\
\hline
\end{tabular}

tumors is connected with the presence of IAP proteins, resulting in cell resistance to apoptosis. This finding is consistent with previous studies conducted in either cell lines or tumor samples [14, 18, 23, 24]. Additionally, Foster et al demonstrated in breast cancer cell lines that the use of a combination of IAP antagonists with proapoptotic agents promotes apoptosis, suggesting that this combination of drugs could offer a clinical benefit in breast cancer patients [23]. Recently published study by Hennessy et al., conducted in cell lines and in breast cancer patients, indicated that the novel dimeric IAP antagonist - compound 14 (AZD5582) is promising candidate for clinical development as an anticancer agent [25].

Despite the presence of XIAP, cIAP-1 cIAP-2 and survivin expression in breast cancer samples at diagnosis we did not confirmed theirs impact to patient's survival, besides the trend

Table 6. Factors associated with probability of OS (univariate analysis log-rank test)

\begin{tabular}{|c|c|c|c|}
\hline Factor & $\mathrm{n}$ & $\begin{array}{c}\text { OS at } \\
50 \text { months } \\
(\%)\end{array}$ & $\mathrm{p}$ \\
\hline Age & & & 0.52 \\
\hline$<50 \mathrm{yr}$ & 12 & 84 & \\
\hline$\geq 50 \mathrm{yr}$ & 80 & 91 & \\
\hline Grade & & & 0.39 \\
\hline G1 & 14 & 100 & \\
\hline G2 and G3 & 78 & 88 & \\
\hline Tumor & & & 0.69 \\
\hline $\mathrm{T} 1$ & 32 & 91 & \\
\hline $\mathrm{T} 2, \mathrm{~T} 3$ & 58 & 89 & \\
\hline Node & & & 0.01 \\
\hline No & 35 & 100 & \\
\hline $\mathrm{N} 1, \mathrm{~N} 2, \mathrm{~N} 3$ & 51 & 79 & \\
\hline ER & & & 0.1 \\
\hline Positive & 71 & 94 & \\
\hline Negative & 21 & 80 & \\
\hline PR & & & 0.11 \\
\hline Positive & 62 & 95 & \\
\hline Negative & 30 & 83 & \\
\hline HER-2 & & & 0.58 \\
\hline Positive & 21 & 86 & \\
\hline Negative & 71 & 92 & \\
\hline Triple negative (ER -, PR-, Her-2 -) & & & 0.57 \\
\hline Yes & 13 & 86 & \\
\hline No & 79 & 91 & \\
\hline XIAP & & & 0.24 \\
\hline$\leq$ Median & 46 & 100 & \\
\hline$>$ Median & 46 & 89 & \\
\hline cIAP-1 & & & 0.78 \\
\hline$\leq$ Median & 46 & 92 & \\
\hline$>$ Median & 46 & 88 & \\
\hline cIAP-2 & & & 0.44 \\
\hline$\leq$ Median & 46 & 94 & \\
\hline$>$ Median & 46 & 87 & \\
\hline Survivin & & & 0.84 \\
\hline$\leq$ Median & 46 & 93 & \\
\hline$>$ Median & 46 & 89 & \\
\hline
\end{tabular}


between longer PFS and lower XIAP expression in tumor cells. In breast cancer prognostic value of IAP family proteins expression is not well defined. To our knowledge this is the first study assessing the prognostic role of cIAP- 1 and cIAP-2 proteins in breast cancer. Most of the studies are focused on survivin. Recently published meta-analysis encompassing 15 studies with total 2,202 breast cancer patients confirmed significant associations between positive expression of survivin and worse overall survival [26]. The prognostic value of XIAP in breast cancer patients was investigated by Zhang $Y$ et al [27]. They reported a significant relationship between nuclear staining of XIAP protein and shorten OS of breast cancer patients.

XIAP protein is recognized as the most potent caspase inhibitor among IAP family members [28]. In our study, expression of XIAP protein was present in almost all breast cancer patients with a significantly higher expression than that of the fibroadenoma samples. Additionally in survival analysis we observed trend to longer PFS of breast cancer patients with lower expression of XIAP protein. These observations may suggest that this IAP member plays an important role in cancerogenesis in breast cancer patients. Similarly, an immunohistochemical assessment showed that XIAP expression was present in $84.3 \%$ of breast invasive ductal carcinoma cases with a high immnoscore [27]. This study also indicates that in breast cancer, the positive ratio and immunoscore of XIAP are significantly higher than those of the Smac/Diablo protein, which is a potent inhibitor of apoptosis protein family members. In our previous study, we also observed a lower expression of Smac/Diablo protein in breast cancer compared to the control, which indicates that Smac/Diablo and XIAP are inversely expressed in this malignancy [29].

IAP family proteins play a similar role in cell resistance to apoptosis. In our study, we observed a correlation between the expressions of XIAP, cIAP-1 cIAP-2 and survivin in all combinations, as well as a relationship between the expression of XIAP and cIAP-1, which indicates the integration of multiple IAP proteins in antiapoptotic mechanism in breast cancer.

The suppression of apoptosis is considered an important mechanism leading both to cancer formation and progression [6]. Therefore it might be expected that expression of antiapoptocic IAP proteins increase with tumor progression. Our data partly confirms this hypothesis, as median expression of XIAP and survivin was markedly higher in more advanced breast cancer (stages pT2/pT3 vs. pT1). Additionally XIAP expression was associated with the presence of the estrogen receptor (ER) in tumors. The relationship between survivin expression and the presence of negative prognostic factors in breast cancer has been confirmed in many studies $[30,31,32]$. Youssef et al. observed that high survivin expression is significantly related to the larger size of the tumor, higher histological grade, lymph node metastases, advanced tumor stage, as well as ER- and progesterone receptor (PR) negative hormonal status of breast cancer [31]. Similarly, Singh et al report a significant relationship between survivin expression and histological grade of invasive ductal breast carcinoma [30]. Adamkov et al confirmed immunohistochemically that survivin is a poor prognostic factor of ductal breast carcinoma, indicating relationships between nuclear expression of survivin and tumor grade 3 and nuclear and cytoplasmic/ nuclear expression and vascular invasion in tumor [32]. However, in other studies, no correlation between the expression of survivin and clinicopathological prognostic factors of breast cancer including tumor size was observed $[14,33]$. Perhaps the changes result from the different cellular locations of survivin [32]. Data concerning XIAP indicates that XIAP expression increases with grade of ductal invasive breast carcinoma, as well as ductal breast carcinoma in situ [34] with no relationship to hormonal receptor status. The ambiguity of the role of XIAP protein in breast cancer behavior should be clarified in a larger survey.

In our study, we observed significantly higher expression of cIAP-2 in node positive breast caner (pN1-N3). No correlations were found between cIAP- 1 protein levels and the clinicopathological features of breast cancer. To our knowledge, until now, there have been no studies determining the role of these proteins in breast cancer. High expression of cIAP- 1 and cIAP- 2 was found to be a poor prognostic factor in bladder cancer patients, where expression of cIAP-1 and cIAP-2 strongly correlates with tumor stage, tumor grade, tumor recurrence and tumor related death [35]. On the other hand, downregulation of cIAP-1 was connected with an unfavorable outcome in renal cell carcinoma [36], all of which may indicate that the function of cIAP- 1 and cIAP-2 and their role in cancer behavior depend on tumor type.

In conclusion we confirmed that XIAP, cIAP- 1 cIAP- 2 and survivin might participate in antiapoptotic mechanisms in breast cancer. However, in short time follow-up we did not observe implications associated with the degree of IAP expression to patient survival. Further studies are needed to establish more complete prognostic and predictive values of IAP family proteins in breast cancer patients.

Acknowledgments: We thank mgr Edward Lowczowski, Foreign Language Teaching Center, Medical University of Lodz, for the review of the manuscript. This work was supported by the Polish Ministry of Science and Higher Education from the financial resources allocated for Science for 2008-2011 (Research Grant No. N N403182234).

\section{References}

[1] OLOFIN I, OLOPADE OL Eliminating global disparities in breast cancer care through clinical research. In: ASCO Educational Book. Alexandria: Virginia; 2009, 681-684

[2] XU Y-L, SUN Q, SHAN Q-L A case-control study on risk factors of breast cancer in China. Arch Med Sci 2012; 8: 303-309. http://dx.doi.org/10.5114/aoms.2012.28558

[3] KOZLOWSKA E, SZEWCZYK MT., BANASZKIEWICZ Z, JAWIEN A, CIERZNIAKOWSKA $\mathrm{K}$ et al. Knowledge of 
symptoms and diagnostic possibilities of cancer diseases. Arch Med Sci 2011; 7: 304-309. http://dx.doi.org/10.5114/ aoms.2011.22082

[4] MCARDLE CS, MCMILLAN DC, GREENLAW N, MORRISON DS Adjuvant radiotherapy and chemotherapy in breast cancer: 30 year follow-up of survival. BMC Cancer 2010; 30: 398. http://dx.doi.org/10.1186/1471-2407-10-398

[5] KERR JFR, WYLLIE AH, CURRIE AR Apotosis: a basic biological phenomenon with wide-ranging implications in tissue kinetics. Br J Cancer 1972; 26: 239-257. http://dx.doi. org/10.1038/bjc.1972.33

[6] HANAHAN D, WEINBERG RA The hallmarks of cancer. Cell 2000; 100: 57-70. http://dx.doi.org/10.1016/S0092-8674(00)81683-9

[7] CROOK NE, CLEM RJ, MILLER LK An apoptosis-inhibiting baculovirus gene with a zinc finger-like motif. J Virol 1993; 67: $2168-2174$

[8] DUBREZ-DALOZ L, DUPOUX A, CARTIER J IAPs: more than just inhibitors of apoptosis proteins. Cell Cycle 2008; 15: 1036-1046. http://dx.doi.org/10.4161/cc.7.8.5783

[9] SMOLEWSKI P, ROBAK T Inhibitors of apoptosis proteins (IAPs) as potential molecular targets for therapy of hematological malignancies. Curr Mol Med 2011; 11: 633-649. http:// dx.doi.org/10.2174/156652411797536723

[10] LI X, YANG Y, ASHWELL JD TNF-RII and c-IAP1 mediate ubiquitination and degradation of TRAF2. Nature 2002; 416: 345-347. http://dx.doi.org/10.1038/416345a

[11] WEI Y, FAN T, YU M Inhibitor of apoptosis proteins and apoptosis. Acta Biochim Biophys Sin 2008; 40: 278-288. http:// dx.doi.org/10.1111/j.1745-7270.2008.00407.x

[12] GRZYBOWSKA-IZYDORCZYK O, CEBULA B, ROBAK T, SMOLEWSKI P Expression and prognostic significance of the inhibitor of apoptosis protein (IAP) family and its antagonists in chronic lymphocytic leukaemia. Eur J Cancer 2010; 46: 800-810. http://dx.doi.org/10.1016/j.ejca.2009.11.023

[13] WATSON RW, FITZPATRICK JM Targeting apoptosis in prostate cancer: focus on caspases and inhibitors of apoptosis proteins. BJU Int 2005; 96: 30-34. http://dx.doi.org/10.1111/ j.1464-410X.2005.05944.X

[14] KENNEDY SM, O'DRISCOLL L, PURCELL R, LINEHAN R, GLYNN S et al. Prognostic importance of survivin in breast cancer. Br J Cancer 2003; 88: 1077-1083. http://dx.doi. org/10.1038/sj.bjc.6600776

[15] ESPOSITO I, KLEEFF J, ABIATARI I, SHI X, GIESE N et al. Overexpression of cellular inhibitor of apoptosis protein 2 is an early event in the progression of pancreatic cancer. J Clin Pathol 2007; 60: 885-895. http://dx.doi.org/10.1136/ jcp.2006.038257

[16] ZHANG S, DING F, LUO A, CHEN A, YU Z, REN S, LIU Z, ZHANG L XIAP is highly expressed in esophageal cancer and its downregulation by RNAi sensitizes esophageal carcinoma cell lines to chemotherapeutics. Cancer Biol Ther 2007; 6: 973-980. http://dx.doi.org/10.4161/cbt.6.6.4195

[17] KIM MA, LEE HE, LEE HS, YANG HK, KIM WH Expression of apoptosis-related proteins and its clinical implication in surgically resected gastric carcinoma. Virchows Arch 2011; 459: 503-510. http://dx.doi.org/10.1007/s00428-011-1150-6
[18] CHEN N, GONG J, CHEN X, MENG W, HUANG Y et al. Caspases and inhibitor of apoptosis proteins in cutaneous and mucosal melanoma: expression profile and clinicopathologic significance. Hum Pathol 2009; 40: 950-956. http://dx.doi. org/10.1016/j.humpath.2008.12.001

[19] AIRD KM, DING X, BARAS A, WEI J, MORSE MA et al. Trastuzumab signaling in ErbB2-overexpressing inflammatory breast cancer correlates with X-linked inhibitor of apoptosis protein expression. Mol Cancer Ther 2008; 7: 38-47. http://dx.doi.org/10.1158/1535-7163.MCT-07$\underline{0370}$

[20] SPAN PN, SWEEP FC, WIEGERINCK ET, TJAN-HEIJNEN VC, MANDERS P et al. Survivin is an independent prognostic marker for risk stratification of breast cancer patients. Clin Chem 2004; 50: 1986-1993. http://dx.doi.org/10.1373/ clinchem.2004.039149

[21] SOHN DM, KIM SY, BAEK MJ, LIM CW, LEE MH et al. Expression of survivin and clinical correlation in patients with breast cancer. Biomed Pharmacother. 2006; 60: 289-292. http://dx.doi.org/10.1016/j.biopha.2006.06.008

[22] EHEMANN V, SYKORA J, VERA-DELGADO J, LANGE A, OTTO HF Flow cytometric detection of spontaneous apoptosis in human breast cancer using the TUNEL-technique. Cancer Lett 2003; 194: 125-131. http://dx.doi.org/10.1016/ S0304-3835(03)00054-5

[23] FOSTER FM, OWENS TW, TANIANIS-HUGHES J, CLARKE RB, BRENNAN $\mathrm{K}$ et al. Targeting inhibitor of apoptosis proteins in combination with ErbB antagonists in breast cancer. Breast Cancer Res 2009; 11: R41. http://dx.doi. org/10.1186/bcr2328

[24] ADAMKOV M, HALASOVA E, KAJO K, MACHALEKOVA K, VYBOHOVA D et al. Survivin: a promising biomarker in breast carcinoma. Neoplasma 2010; 57:572-577. http://dx.doi. org/10.4149/neo $2010 \quad 06 \quad 572$

[25] HENNESSY EJ, ADAM A, AQUILA BM, CASTRIOTTA LM, COOK D et al. Discovery of a novel class of dimeric smac mimetics as potent iap antagonists resulting in a clinical candidate for the treatment of cancer (AZD5582). J Med Chem 2013; 56: 9897-919. http://dx.doi.org/10.1021/ jim401075x

[26] SONG J, SU H, ZHOU YY, GUO LL Prognostic value of survivin expression in breast cancer patients: a meta-analysis. Tumour Biol 2013; 34: 2053-2062. http://dx.doi.org/10.1007/ s13277-013-0848-2

[27] ZHANG Y, ZHU J, TANG Y, LI F, ZHOU H et al. X-linked inhibitor of apoptosis positive nuclear labeling: a new independent prognostic biomarker of breast invasive ductal carcinoma. Diagn Pathol 2011; 6: 49. http://dx.doi. org/10.1186/1746-1596-6-49

[28] RAJCAN-SEPAROVIC E, LISTON P, LEFEBVRE C, KORNELUK RG Assignment of human inhibitor of apoptosis protein (IAP) genes xiap, hiap-1, and hiap-2 to chromosomes $\mathrm{Xq} 25$ and 11q22-q23 by fluorescence in situ hybridization. Genomics 1996; 37: 404-406. http://dx.doi.org/10.1006/ geno.1996.0579

[29] PLUTA P, CEBULA-OBRZUT B, EHEMANN V, PLUTA A, WIERZBOWSKA A et al. Correlation of Smac/DIABLO 
protein expression with the clinico-pathological features of breast cancer patients. Neoplasma 2011; 58: 430-435. http:// dx.doi.org/10.4149/neo $2011 \quad 05 \quad 430$

[30] SINGH M, BLEILE MJ, SHROYER AL, HEINZ D, JARBOE EA, SHROYER KR Analysis of survivin expression in a spectrum of benign to malignant lesions of the breast. Appl Immunohistochem Mol Morphol 2004; 12: 296-304. http:// dx.doi.org/10.1097/00129039-200412000-00003

[31] YOUSSEF NS, HEWEDI IH, ABD RABOH NM. Immunohistochemical expression of survivin in breast carcinoma: relationship with clinicopathological parameters, proliferation and molecular classification. J Egypt Natl Canc Inst 2008; 20: 348-357

[32] ADAMKOV M, KAJO K, VYBOHOVA D, KRAJCOVIC J, STULLER F et al. Correlations of survivin expression with clinicomorphological parameters and hormonal receptor status in breast ductal carcinoma. Neoplasma 2012; 59: 30-7. http://dx.doi.org/10.4149/neo 2012004
[33] TANAKA K, IWAMOTO S, GON G, NOHARA T, IWAMOTO M, TANIGAWA N. Expression of survivin and its relationship to loss of apoptosis in breast carcinomas. Clin Cancer Res. 2000; 6: 127-34

[34] JAFFER S, ORTA L, SUNKARA S, SABO E, BURSTEIN DE. Immunohistochemical detection of antiapoptotic protein X-linked inhibitor of apoptosis in mammary carcinoma. Hum Pathol 2007; 38: 864-870. http://dx.doi.org/10.1016/j.humpath.2006.11.016

[35] CHE X, YANG D, ZONG H, WANG J, LI X et al. Nuclear cIAP1 overexpression is a tumor stage- and gradeindependent predictor of poor prognosis in human bladder cancer patients. Urol Onco. 2012; 30: 450-456. http://dx.doi. org/10.1016/j.urolonc.2010.12.016

[36] KEMPKENSTEFFEN C, HINZ S, CHRISTOPH F, KOLLERMANN J, KRAUSE H et al. Expression parameters of the inhibitors of apoptosis cIAP1 and CIAP2 in renal cell carcinomas and their prognostic relevance. Int J Cancer 2007; 120: 1081-1086. http://dx.doi.org/10.1002/ijc.22416 